\title{
Inactivation of Cryptosporidium parvum oocysts and faecal indicator bacteria in cattle slurry by addition of ammonia
}

Petersen, H.H.; Dalsgaard, A.; Vinneras, B.; Jensen, L.S.; Le, T.T.A.; Petersen, M.A.; Enemark, H.L.; Forslund, A.

Published in:

Journal of Applied Microbiology

Link to article, DOI:

10.1111/jam. 14881

Publication date:

2021

Document Version

Peer reviewed version

Link back to DTU Orbit

Citation (APA):

Petersen, H. H., Dalsgaard, A., Vinneras, B., Jensen, L. S., Le, T. T. A., Petersen, M. A., Enemark, H. L., \& Forslund, A. (2021). Inactivation of Cryptosporidium parvum oocysts and faecal indicator bacteria in cattle slurry by addition of ammonia. Journal of Applied Microbiology, 130(5), 1745-1757. https://doi.org/10.1111/jam.14881

\section{General rights}

Copyright and moral rights for the publications made accessible in the public portal are retained by the authors and/or other copyright owners and it is a condition of accessing publications that users recognise and abide by the legal requirements associated with these rights.

- Users may download and print one copy of any publication from the public portal for the purpose of private study or research.

- You may not further distribute the material or use it for any profit-making activity or commercial gain

- You may freely distribute the URL identifying the publication in the public portal 
2 MRS. HEIDI HUUS PETERSEN (Orcid ID : 0000-0002-7208-7614)

3 PROF. LARS STOUMANN JENSEN (Orcid ID : 0000-0002-1446-2084)
4
5
6 Article type : Original Article
7
8

9 Inactivation of Cryptosporidium parvum oocysts and faecal

\section{0 indicator bacteria in cattle slurry by addition of ammonia}

11 Running title: Inactivation of parasites and bacteria in slurry

12 Petersen, H.H. ${ }^{a, b^{*}}$, Dalsgaard, A. ${ }^{b}$, Vinneras, B. ${ }^{c}$, Jensen, L.S. ${ }^{d}$ Le, T.T.A. ${ }^{b}$, Petersen, M.A. ${ }^{f}$, Enemark, H.L. ${ }^{a}, g$ and 13 Forslund, A. ${ }^{b}$

14 A National Veterinary Institute, Technical University of Denmark, Kemitorvet, 2800 Kgs. Lyngby, Denmark

15 bDepartment of Veterinary and Animal Sciences, Faculty of Health and Medical Sciences, University of 16 Copenhagen, Frederiksberg, Denmark

17 c Swedish University of Agricultural Sciences, Department of Energy and Technology, SE-750 07 Uppsala, 18 Sweden

19 dDepartment of Plant and Environmental Sciences, Faculty of Science, University of Copenhagen, 20 Frederiksberg, Denmark

21 f Department for Palliative Medicine, The Research Unit, Bispebjerg Hospital, Copenhagen NV, Denmark

22 g present address: Department of Animal Health and Food Safety, Norwegian Veterinary Institute, P.O. Box 23750 Sentrum, NO-0106 Oslo, Norway

This article has been accepted for publication and undergone full peer review but has not been through the copyediting, typesetting, pagination and proofreading process, which may lead to differences between this version and the Version of Record. Please cite this article as doi: $\underline{10.1111 / J A M .14881}$

This article is protected by copyright. All rights reserved 
*Corresponding author. Tel.: +45 408369 35;

E-mail address: hhpet@vet.dtu.dk

This article is protected by copyright. All rights reserved 


\section{ABSTRACT}

27 Aims: To determine inactivation of Cryptosporidium parvum oocysts and reduction of Escherichia coli and 28 enterococci in cattle slurry added aqueous ammonia.

29 Methods and Results: Escherichia coli, enterococci and non-viable C. parvum oocysts (DAPI+ PI+) were 30 enumerated every second day for two weeks in cattle slurry amended with $60 \mathrm{mmol} \mathrm{I}^{-1} \mathrm{aq}$. ammonia and 31 compared with untreated slurry at three temperatures. Regardless of temperature, the proportion of non32 viable $C$. parvum oocysts increased significantly faster over time in slurry with added ammonia than raw 33 slurry $(p=0.021)$ corresponding to $62.0 \%$ higher inactivation $(P=0.001)$ at day 14 . Additionally, $91.8 \%$ fewer 34 E. coli and $27.3 \%$ fewer enterococci was observed slurry added ammonia at day 14 compared raw slurry.

35 Conclusion: The addition of aqueous ammonia to raw slurry significantly reduced the viability of $C$. parvum 36 oocysts and numbers of bacterial indicators. Hence, ammonia is usable to lower pathogen concentrations 37 in slurry prior before application to agricultural land.

38 Significance and Impact of Study: Livestock waste is a valuable source of plant nutrients and organic 39 matter, but may contain high concentrations of pathogens like Escherichia coli and Cryptosporidium spp. 40 that can be spread in the environment, and cause disease outbreaks. However, die-off rates of pathogens 41 in organic waste can increase following increasing ammonia concentrations.

42 Keywords: Cryptosporidium parvum; Escherichia coli; Enterococci; faecal indicator bacteria; Cattle slurry; $43 \quad$ Ammonia

This article is protected by copyright. All rights reserved 


\section{INTRODUCTION}

45 Livestock waste is a valuable source of plant nutrients and organic matter and is used to fertilize 46 agricultural land. Unfortunately, livestock waste may contain large quantities of microorganisms pathogenic

47 to humans (Hutchison et al., 2005b), including the zoonotic protozoan parasite Cryptosporidium parvum, 48 Salmonella spp. and Escherichia coli. Following livestock waste application to agricultural land, pathogens 49 can contaminate crops or the aquatic environment (Bodley-Tickell et al., 2002; Islam et al., 2004; Ong et al., 50 1996; Pelly et al., 2007) potentially constituting a public health risk. Dispersal of pathogens from animal 51 faeces relies on rain to release the pathogens from the faecal matrix or slurry, and surface runoff water 52 then contaminates water bodies serving as recreational, irrigation, or drinking water sources.

53 In 2007 in Galway, Ireland, approx. 182 people were infected with Cryptosporidium oocysts contracted 54 from a lake, which was apparently contaminated by water runoff from agricultural land following 55 application of slurry in a wet winter (Pelly et al., 2007). In Walkerton, Canada, E. coli O157:H7 and 56 Campylobacter jejuni infections resulted in 2,300 cases of illness and seven deaths among individuals who 57 consumed drinking water from a municipal water supply contaminated with pathogens originating from a 58 nearby farm, where cattle manure was applied to agricultural fields and subsequently washed into the 59 water reservoir (Clark et al., 2003; Hrudey et al., 2003). Due to expected increased heavy rain events 60 related to climate changes, slurry-contaminated surface runoff water from fields will probably be a growing 61 source of pathogen contamination in certain parts of the world.

62 Abu-Ashour and Lee (2000) studied E. coli overland transport at field sites with $2 \%$ and $6 \%$ slopes during 63 surface water runoff events in which grass-covered plots were contaminated by pouring water containing 64 E. coli on the surface using watering cans. Escherichia coli was released from the slurry by this simulated 65 rainfall event and 15 and $16 \mathrm{CFU}$ E. coli $\mathrm{mL}^{-1}$ were isolated in runoff water $20 \mathrm{~m}$ and $30 \mathrm{~m}$, respectively, 66 from the initial location (Abu-Ashour and Lee, 2000). Furthermore, oocysts was detected in runoff water 67 from manure containing C. parvum oocysts and applied to agricultural land (Thurston-Enriquez et al., 2005). 68 In addition, rain events can cause vertical transport of slurry-borne microorganisms, resulting in shallow 69 groundwater contamination (Forslund et al., 2011; Mawdsley et al., 1996; Petersen et al., 2012). 70 Compounding this issue, Cryptosporidium is infectious at low dosages (Okhuysen et al., 1999) and oocysts 71 possess very robust multi-layered structures (Harris and Petry, 1999) resistant to e.g. periods of freezing 72 (Robertson et al., 1992), and commonly utilized water disinfectants such as chlorine (Korich et al., 1990; 73 Shields et al., 2008; Venczel et al., 1997). Therefore, pre-treating slurry can be useful to inactivating oocysts 74 prior to application to agricultural land, thereby preventing contamination of water and food sources. High 75 temperature and exposure to ammonia are some of few stressors that can inactivate oocysts (Jenkins et al., This article is protected by copyright. All rights reserved 
1998; Li et al., 2010; Reinoso et al., 2008), stressors, which potentially are available in slurry tanks. In

77 Denmark, slurry is usually stored in large tanks for approx. six months and then applied to fields during 78 spring and autumn (Vinnerås, 2013). However, during storage, fresh slurry is most often added 79 continuously to the tanks, resulting in short storage time for fractions of the slurry and limited time for 80 pathogen reduction and a corresponding risk of transmission to the external environment (Hutchison et al., 81 2005a; Vinnerås, 2013). By adding a known concentration of ammonia to the slurry tank, it is guaranteed 82 that all oocysts are exposed to equal ammonia concentrations. However, reduction rates are lacking for 83 Cryptosporidium in slurry, since previous studies have focused on oocyst survival in faecal pats, soil and 84 water. Slurry contains much more native ammoniacal $\mathrm{N}$ than most other products studied. Previous studies 85 on Cryptosporidium oocysts stored in distilled water or Hank's balanced salt solution (HBSS), and exposed 86 to ammonia have showed that oocysts were increasingly inactivated with increasing ammonia 87 concentration (Jenkins et al., 1998; Reinoso et al., 2008), e.g., 99.9\% oocysts were inactivated after an 88 estimated 10.2 days when exposed to $60 \mathrm{mmol} \mathrm{l}^{-1}$ ammonia, compared with 17.8 days when exposed to 26 $89 \mathrm{mmol} \mathrm{l}^{-1}$ ammonia (Jenkins et al., 1998). Moreover, a good sanitization effect of ammonia in reducing other 90 pathogens have been documented in faecal wastes (Mendez et al., 2004; Nordin et al., 2013; 91 Watcharasukarn et al., 2009). The effect of ammonia is considerably stronger than of $\mathrm{OH}^{-}$, and a recent 92 study of Senecal et al. (2020) showed that even at pH 12 additional factors such as ammonia or heat were 93 required for inactivation of Ascaris eggs. In a study with $20 \% \mathrm{w} / \mathrm{w}$ ammonia added to slurry, concentrations 94 of faecal coliforms were reduced by $7 \mathrm{log}$, Salmonella spp. by $6 \log$, and $83 \%$ of viable helminth eggs were 95 reduced within a contact time of $2 \mathrm{~h}$ (Mendez et al., 2004). Moreover, the decimal reduction time $\left(T_{90}\right)$ 96 equivalent to 1 -log reduction of Salmonella inoculated in bovine manure added $0.5 \%$ aqueous (aq.) 97 ammonia and stored at $4{ }^{\circ} \mathrm{C}$ was 1.1 day, compared with 34 days in raw slurry (Ottoson et al., 2008a). There 98 is an apparent linear relationship between Salmonella and E. coli inactivation rates following ammonia 99 treatment, while enterococci appear more resistant to ammonia treatment (Himathongkham and Riemann, 100 1999; Nordin, 2010; Ottoson et al., 2008a).

101 The ammonia addition serves two purposes, firstly it is an efficient treatment method for pathogen 102 inactivation. Secondly, as the ammonia is not consumed during the treatment, the treatment needs to be 103 performed in systems with roof to assure that the ammonia is not ventilated away, the ammonia will then 104 add upon the nutrient content when the slurry is applied in the field. Thereby, no additional $\mathrm{N}$ fertilisation 105 will be required during the growing season. However, in areas with high $\mathrm{N}$ overload from agriculture due to 106 too high animal density, this method will not be applicable as it will add to the total nitrogen overload. The 107 method is more applicable in areas with moderate animal density where mineral fertilisers complement the 108 use of animal manure in food and feed production.

This article is protected by copyright. All rights reserved 
109 The objective of the present study was to determine if $C$. parvum oocysts could be inactivated and E. coli 110 and enterococci reduced below the detection limit in cattle slurry prior to land application by adding 60 $111 \mathrm{mmol} \mathrm{l^{-1 }}$ aq. ammonia, and storing it at temperatures corresponding to the typical variation in ambient 112 temperatures in Denmark.

\section{2. MATERIALS AND METHODS}

114 Slurry originated from a slurry tank on a conventional dairy farm in Store Heddinge, Denmark. Properties of 115 the slurry are described in Table 1 . The $\mathrm{pH}$ and electrical conductivity were measured directly in the slurry 116 with a combination tester HI 98130 (Th Geyer, Roskilde, Denmark). Dry matter content was determined by 117 oven drying at $105^{\circ} \mathrm{C}$. Cryptosporidium oocysts were determined in $2 \mathrm{~g}$ of slurry as described in Petersen et 118 al. (2012). Briefly, Cryptosporidium-positive faecal samples were suspended in tap water, filtered through 119 gauze, centrifuged and the supernatant discarded. This washing procedure was repeated 2-3 times. Tap 120 water was added to increase the volume to 5-10 $\mathrm{ml}$. The faecal solution was underlayered with a gradient 121 consisting of 1.09/1.05/1.01 Percoll (Amersham Biosciences, Australia), centrifuged at 1,540 x g for $10 \mathrm{~min}$, 122 and oocysts were collected between the 1.09/1.05 Percoll layers. Purified oocysts were washed three times 123 to remove Percoll, and the oocysts were then enumerated by immunofluorescence microscopy as 124 described in 2.3. The concentrations of $E$. coli and enterococci, and total ammoniacal nitrogen (TAN) were 125 determined as described in sections 2.4 and 2.5 , respectively.

126 The collected slurry only contained $8 \pm 1.2$ oocysts $L^{-1}$ (Table 1 ) and was therefore spiked with $C$. parvum 127 oocysts. These oocysts originated from a field isolate from a Danish Holstein calve naturally infected with $C$. 128 parvum. The calve was diagnosed by the modified Ziehl-Neelsen technique (Henriksen and Pohlenz, 1981) 129 and oocysts subsequently concentrated as previously described by Petersen et al. (2012). The viability of 130 the concentrated oocysts was analysed as described in section 2.3 and the oocysts were identified to the 131 species level as described by Langkjær et al. (2007).

\section{2.1. Experimental design}

133 Every second day throughout 14 days, inactivation of C. parvum oocysts and reduction of E. coli and 134 enterococci in cattle slurry was determined at various temperatures $\left(4^{\circ} \mathrm{C}, 10^{\circ} \mathrm{C}\right.$ and $\left.20^{\circ} \mathrm{C}\right)$ following the 135 addition of concentrated aq. ammonia (25\% $\mathrm{NH}_{3}$ by weight) (Table 2). These temperatures correspond to 136 the typical variation in ambient temperatures in Denmark.

137 The cattle slurry was placed in a $5 \mathrm{~L}$ plastic container on a magnetic stirrer and $10 \mathrm{~g}$ portions of slurry were 138 added to either $15 \mathrm{ml}$ blue cap centrifugation tubes $(\mathrm{n}=144)$ or $50 \mathrm{ml}$ blue cap centrifugation tubes $(\mathrm{n}=144)$

This article is protected by copyright. All rights reserved 
139 (Table 2) leaving approx. $30-40 \mathrm{ml}$ headspace in the $50 \mathrm{ml}$ tubes and approx. $5 \mathrm{ml}$ headspace in the $15 \mathrm{ml}$ 140 tubes. The tubes were then stored in incubators at 4,10 , or $20^{\circ} \mathrm{C}$ overnight for the slurry to reach the 141 required temperature prior to start of the experiment. Slurry in the $15 \mathrm{ml}$ blue cap centrifugation tubes was 142 used for E. coli and enterococci measurements $(n=144)$, while slurry in the $50 \mathrm{ml}$ blue cap centrifugation 143 tubes were spiked with approx. $2.2 \times 10^{5} \mathrm{C}$. parvum oocysts $(n=144)$. Escherichia coli and enterococci were 144 present in sufficient numbers in the slurry (Table 1 ) and spiking was unnecessary. Aqueous ammonia was 145 added to $50 \%$ of both $15 \mathrm{ml}(n=72)$ and $50 \mathrm{ml}(n=72)$ tubes (Table 2). The tubes were immediately sealed 146 with a lid to avoid vaporization, mixed well by shaking and placed in incubators at 4,10 or $20^{\circ} \mathrm{C}$ together 147 with the remaining $(n=72 \times 2)$ of the tubes which acted as controls and contained raw slurry with no added 148 aq. ammonia (Table 2). Inactivation of $C$. parvum oocysts, reduction of $E$. coli and enterococci, $\mathrm{pH}$ and Total 149 ammonium $\mathrm{N}$ (TAN) were determined in triplicate samples every second day for 14 days (Table 2).

150 To determine if increased $\mathrm{pH}$ values affected oocyst inactivation in the slurry, $10 \mathrm{ml}$ buffer with $\mathrm{pH}$ of seven 151 and nine (Th. Geyer, Roskilde, Denmark) were spiked with approx. $2.2 \times 10^{5} \mathrm{C}$. parvum oocysts and 152 incubated together with the slurry.

153 To achieve identical uncharged $\mathrm{NH}_{3}$ concentrations in slurry samples incubated at different temperatures, 154 the volume of aq. ammonia added to reach a final uncharged $\mathrm{NH}_{3}$ concentration of approx. 60 mmol $\mathrm{I}^{-1}$ was 155 determined for each incubation temperature prior to start of the experiment. The target concentration of $15660 \mathrm{mmol} \mathrm{I}^{-1} \mathrm{NH}_{3}$ was chosen since it has previously been demonstrated to inactivate $99.9 \%$ of the oocysts 157 within 14 days in distilled water (Jenkins et al., 1998). The specific concentration was reached by 158 incremental addition of aq. ammonia to a predefined volume of slurry and measurement of $\mathrm{pH}$, to create 159 an ammonia standard curve. In brief, $100 \mathrm{ml}$ slurry were placed in a beaker on a magnetic stirrer, $250 \mu \mathrm{l}$ aq. 160 ammonia were added at once, the slurry was stirred for $1 \mathrm{~min}$, and the $\mathrm{pH}$ was measured. The procedure 161 was repeated until 5,000 $\mu \mathrm{L}$ aq. ammonia was added. Uncharged $\mathrm{NH}_{3}$ along the standard curve was then 162 calculated for each incubation temperature according to the following formula (Vinnerås, 2013):

$$
\left[\mathrm{NH}_{3}\right]=\frac{[\mathrm{TAN}] \times K_{a}}{K_{a}+\left[\mathrm{H}^{+}\right]}
$$

163 Where TAN is total ammoniacal $\mathrm{N}$ and the dissociation constant $K_{a}$, varies with temperature (T, Kelvin), and 164 pKa (defined as $-\log _{10}[K a]$ ) which is related to $T$ by:

$$
\mathrm{pK}_{\mathrm{a}}=\frac{2728.9}{\mathrm{~T}}+0.090181
$$

165 The theoretical requirement of TAN to be added as aq. ammonia per $10 \mathrm{ml}$ of slurry to reach the same 166 uncharged calculated $\mathrm{NH}_{3}$ concentration was estimated.

This article is protected by copyright. All rights reserved 
Based on this, $125 \mu \mathrm{l}\left(4^{\circ} \mathrm{C}\right), 100 \mu \mathrm{l}\left(10^{\circ} \mathrm{C}\right)$, or $88 \mu \mathrm{l}\left(20^{\circ} \mathrm{C}\right)$ aq. ammonia, corresponding to uncharged $\mathrm{NH}_{3}$ 168 concentrations of 67,64 , and $57 \mathrm{mM}$ (as close as possible to the target concentration of $60 \mathrm{mM}$ ), 169 respectively, were added at day 0 . It was assumed that due to the high solubility of $\mathrm{NH}_{3}$ in water $\left(\mathrm{Henry}^{\prime} \mathrm{s}\right.$ 170 constant, $\mathrm{K}_{\mathrm{H}}$ of $60 \mathrm{~mol} \mathrm{I}_{\mathrm{aq}}^{-1} \mathrm{~atm}^{-1}$ at $25{ }^{\circ} \mathrm{C}$ and higher at lower temperatures (Sommer et al., 2013)), very 171 little of the added $\mathrm{NH}_{3}$ will be equilibrated in the headspace during incubation.

\section{$172 \quad$ 2.2. Isolation of C. parvum oocysts from slurry}

173 Cryptosporidium parvum oocysts were isolated from slurry samples ( $\mathrm{n}=63$; Table 2) by immunomagnetic 174 separation (IMS) with modifications (Dynabeads ${ }^{\circledR}$ Anti-Cryptosporidium Kit, Life technologies, Nærum, 175 Denmark). Briefly, $1.5 \mathrm{ml}$ slurry from each sample was added to a L10 tube, diluted to $10 \mathrm{ml}$ with $\mathrm{MQ}$ water

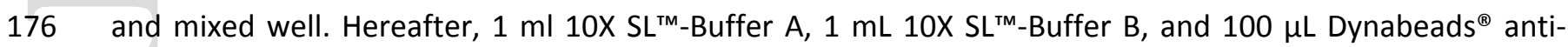
177 Cryptosporidium were added. The subsequent oocyst isolation was carried out according to the 178 manufacturer's instructions.

\section{2.3. Assessment of $\boldsymbol{C}$. parvum oocyst inactivation in cattle slurry}

180 Oocyst inactivation was assessed by scoring oocysts according to inclusion or exclusion of the vital dyes 181 4',6-diamidino-2-phenylindole (DAPI) and propidium iodide (PI). In brief, purified oocysts obtained by IMS 182 was incubated simultaneously with $10 \mu \mathrm{l}$ DAPI working solution (2 mg ml-1 in absolute methanol) (Sigma, 183 Sigma-Aldrich Denmark ApS) and $10 \mu \mathrm{PI}$ working solution ( $1 \mathrm{mg} \mathrm{ml}^{-1}$ in $0.1 \mathrm{M}$ phosphate buffered saline 184 (PBS, pH 7.2); Sigma, Sigma-Aldrich Denmark ApS). Following $3 \mathrm{~h}$ incubation at $37{ }^{\circ} \mathrm{C}$, each sample was 185 washed twice in MQ water by centrifugation at $3500 \times g$ for 5 min and removal of the supernatant down to 186 approx. $100 \mu \mathrm{l}$. The entire sample was then placed in a well on a three-well (12 mm) teflon printed 187 diagnostic slide (Immono-Cell, Mechelen, Belgium). The slide was air-dried, fixed for 5 min with acetone, 188 and $25 \mu \mathrm{l}$ anti-Cryptosporidium fluorescein isothiocyanate (FITC)-labelled antibody mix (Crypto-Cell IF test,

189 Cellabs, Australia) were added according to the manufacturer's instructions. Characterization of inactivated 190 oocysts was based on inclusion and exclusion of vital dyes. Oocysts that included both dyes (DAPI-positive, 191 PI-positive (DAPI+ $\mathrm{PI}+)$ ) were characterized as non-viable (inactivated). Approx. 100 oocysts from each 192 sample were quantified using an epifluorescence microscope at 400x magnification (Leica DMRA2) and 193 subsequently the percentage of non-viable oocysts was calculated. Assuming a total population of 10,000 194 oocysts: If repeatedly, randomly sampling 100 oocysts out of the overall population, $80 \%$ of the samples 195 will have an inactivation estimate that differs $<=6 \%$ from the true level, i.e., there is an $80 \%$ probability of 196 obtaining an estimate within then range $54-66 \%$, if the true level is $60 \%$. In $96 \%$ of the cases, the deviation 197 will be $<10 \%$.

This article is protected by copyright. All rights reserved 
198 The microscope was equipped with the following filter blocks: $350 \mathrm{~nm}$ excitation, $450 \mathrm{~nm}$ emissions for 199 DAPI; $500 \mathrm{~nm}$ excitation, $630 \mathrm{~nm}$ emissions for PI; and $495 \mathrm{~nm}$ excitation, $519 \mathrm{~nm}$ emission wavelengths for 200 FITC.

\section{$201 \quad$ 2.4. Bacteriological analysis}

202 For the E. coli and enterococci analysis, 10-fold dilutions of slurry were prepared in Maximum Recovery 203 Dilution (MRD) (Oxoid, Basingstoke,UK) and surface-spread onto Brilliant E. coli/coliform Selective Agar 204 (Oxoid, Basingstoke,UK) and Slanetz \& Bartley Agar plates (Oxoid, Basingstoke,UK), respectively. For the $E$. 205 coli analysis, the Brilliant E. coli/coliform Selective Agar plates were incubated at $37^{\circ} \mathrm{C}$ for $24 \mathrm{~h}$ and purple 206 colonies were counted. Enterococci were determined as typical red-maroon colonies on Slanetz \& Bartley

207 Agar following incubation at $44{ }^{\circ} \mathrm{C}$ for $48 \mathrm{~h}$. Detection limit for both indicator bacteria was $1 \mathrm{CFU} \mathrm{ml}{ }^{-1}$.

208 2.5. Physico-chemical analysis

209 The $\mathrm{pH}$ was measured directly in all replicate slurry samples on each sampling day (Table 2) with a 210 combination tester HI 98130 (Th Geyer, Roskilde, Denmark). The pH was then lowered in $5 \mathrm{~g}$ slurry in all 211 replicate slurry samples (Table 2$)$ by diluting it 1:20 in $1 \mathrm{~mol} \mathrm{l}^{-1} \mathrm{KCl}\left(74.56 \mathrm{~g} \mathrm{~mol}_{-1}\right)$. The diluted slurry was 212 shaken on a shaker table at $170 \mathrm{rpm}$ in $45 \mathrm{~min}$, left to sediment for $45 \mathrm{~min}$, and $15 \mathrm{ml}$ of the supernatant 213 filtered through a filter paper (Advantec $5 \mathrm{~A}$, Frisennette Aps, Denmark). The filtrate was stored at $-20^{\circ} \mathrm{C}$ for 214 later ammonium analysis. Total ammonium N (TAN) was measured spectrophotometrically on a Foss 215 FIAstar 5000 flow injection analysis system. The concentration of uncharged $\mathrm{NH}_{3}$ in each individual tube 216 was then calculated according to equation (1) and (2) (Vinnerås, 2013), based on TAN, pH and incubation 217 temperature.

\section{2.6. Data analysis}

219 In order to obtain variance homogeneity, the natural logarithm (In) was used to transform the following 220 data as outcome variables in standard multiple linear regression models: calculated uncharged NH3 221 concentration, $\mathrm{pH}$, proportion of non-viable (DAPI+ $\mathrm{PI}+$ ) oocysts, E. coli, and enterococci. The following 222 variables were analysed as potential explanatory variables: treatment (raw slurry and slurry with added aq. 223 ammonia), incubation temperature $\left(4^{\circ} \mathrm{C}, 10^{\circ} \mathrm{C}, 20^{\circ} \mathrm{C}\right)$, and time (modelled as a continuous variable). The 224 normality assumption was validated by quantile-quantile plots, and variance homogeneity was validated by 225 residual plot. To improve fit, pathogen levels were normalized by transforming to $\ln (x)$ and the normality 226 assumption was validated by quantile-quantile plots, and variance homogeneity was validated by residual 227 plot. To fit E. coli to a standard linear regression model, time was transformed using $\ln (x+1)$. For all 228 outcomes, non-significant effects were removed by stepwise backward model reduction using a 5\% 229 significance level starting with the model with the three-factor interaction of treatment*incubation This article is protected by copyright. All rights reserved 
temperature*time. All mean \pm Standard error of the mean (SEM) values are the geometric mean and

231 geometric standard error of the mean. The percentage of non-viable oocysts was calculated based on the 232 best-fitted line shown in Fig. 2.

233 The statistical analyses were conducted using SAS v. 9.3 [1].

\section{3. RESULTS}

\section{3.1. Ammonia and pH}

236 Figures $1 \mathrm{~A}$ and $1 \mathrm{~B}$ show the geometric mean and $95 \% \mathrm{Cl}$ of $\mathrm{pH}$ and calculated uncharged $\mathrm{NH}_{3}$ concentration 237 in cattle slurry over time for the various treatments.

238 The mean \pm SEM pH at day 0 independent of temperature was $8.5 \pm 0.03$ in the raw slurry, while the 239 addition of ammonia to slurry increased the $\mathrm{pH}$ to $9.7 \pm 0.01$. The $\mathrm{pH}$ in raw slurry increased significantly 240 over time $(\mathrm{p}<0.0001)$, while there was no change in $\mathrm{pH}$ in slurry with added ammonia. The changes in $\mathrm{pH}$ 241 over time were unaffected by incubation temperature in raw slurry as well as slurry with added ammonia 242 (Fig. 1A).

243 The mean \pm SEM uncharged $\mathrm{NH}_{3}$ concentration at day 0 was $3.2 \pm 0.2,6.7 \pm 0.6$ and $16.5 \pm 1.6 \mathrm{mmol} \mathrm{I}^{-1}$ at 4 , 24410 and $20^{\circ} \mathrm{C}$ in raw slurry, and $71.6 \pm 5.1,88.0 \pm 2.3$ and $121.0 \pm 1.5 \mathrm{mmol} \mathrm{I}^{-1}$ at 4,10 and $20{ }^{\circ} \mathrm{C}$ in ammonia 245 treated slurry, corresponding to 68.4-104.5 higher mmol $\mathrm{I}^{-1}$ in ammonia treated slurry than in raw slurry at 246 day 0.

247 In raw slurry, the uncharged $\mathrm{NH}_{3}$ concentration increased significantly over time $(p<0.0001)$, but the 248 increase was unaffected by the incubation temperature.

249 In the ammonia treated slurry, the uncharged $\mathrm{NH}_{3}$ concentration was constant over time and almost 250 unaffected by incubation temperature (Fig. 1B). Hence, the desired uncharged $\mathrm{NH}_{3}$ concentration was 251 achieved throughout the study in slurry with added ammonia, regardless of temperature.

\section{$252 \quad 3.2$. Cryptosporidium oocysts}

253 Of the oocysts used for spiking, $12.0 \%$ were categorized as non-viable (DAPI+ PI+) at day 0.

254 Both in slurry with added ammonia and in raw slurry, the proportion of non-viable oocysts significantly $255(P<0.0001 ; P=0.0003)$ increased over time (Fig. 2). However, incubation temperatures did not affect the 256 inactivation of oocysts neither in raw slurry nor in slurry added ammonia (data not shown).

This article is protected by copyright. All rights reserved 
257 When disregarding the incubation temperature, the proportion of non-viable oocysts increased significantly 258 within 14 days in slurry added ammonia (increased by 28.5\%) than in raw slurry (increased 10.8\%) (Fig. 2), 259 resulting in $40.4 \%$ non-viable oocysts in slurry added ammonia and $22.8 \%$ non-viable oocysts in raw slurry 260 at day 14 . This correspond to $62.0 \%$ higher inactivation ( $P=0.001)$ of oocysts in slurry added ammonia at 261 day 14 (mean concentration $95.3 \pm 4.54 \mathrm{mmol} \mathrm{l}^{-1}$ ammonia).

262 The correlations between uncharged $\mathrm{NH}_{3}$ and non-viable oocysts were moderate $(r=0.58$ and $r=0.56)$ 263 (data not shown).

264 No significant differences were observed in the proportion of non-viable oocyst following 14 days of 265 storage in buffer with $\mathrm{pH} 7$ or 9 (data not shown).

\section{3.3. Bacterial indicators}

267 Enterococci were naturally present in slurry, with a mean initial concentration of $1.6 \times 10^{4} \pm 2.5 \times 10^{3} \mathrm{CFU}$ $268 \mathrm{ml}^{-1}$ (Table 1). Enterococci concentration was reduced faster at $20{ }^{\circ} \mathrm{C}$ than at $4{ }^{\circ} \mathrm{C}(\mathrm{P}=0.019)$ or $10{ }^{\circ} \mathrm{C}$ $269(\mathrm{P}=0.004)$ in the slurry with added ammonia (Fig. 3A). The enterococci concentrations following incubation 270 at $4{ }^{\circ} \mathrm{C}$ and $10{ }^{\circ} \mathrm{C}$ were not significantly different, and no differences in reduction was correlated to 271 incubation temperature in raw slurry (Fig. 3B). When the incubation temperature was disregarded, the 272 addition of ammonia to slurry resulted in a significantly faster reduction of enterococci over time $(P=0.006)$ 273 compared with raw slurry, corresponding to $27.3 \%$ fewer enterococci in slurry added ammonia than in raw 274 slurry at day 14. Based on the standard linear regression model, the estimated mean time for a 1 log 275 reduction $\left(T_{90}\right)$ ranged from 33.9 to 77.8 days in the slurry with added ammonia, compared with 66.6-175.3 276 days in the raw slurry.

277 Likewise, E. coli was naturally present in the slurry with an initial concentration of $68 \pm 28 \mathrm{CFU} \mathrm{ml}^{-1}$ (Table 278 1). Since $E$. coli concentration in the slurry was reduced rapidly within the first couple of days, time was In $279(x+1)$ transformed to enable linear modelling of the correlation between $E$. coli and time by a standard 280 linear regression model. Based on this model, the concentration of $E$. coli CFU $\mathrm{ml}^{-1}$ was significantly reduced 281 over time in both raw slurry and slurry with added ammonia. No difference in reduction was noted in 282 correlation to incubation temperature in slurry with added ammonia ( $P=0.176)$ (Fig. $3 \mathrm{~A})$, while in raw slurry 283 E. coli was reduced faster at $20^{\circ} \mathrm{C}$ than at $4{ }^{\circ} \mathrm{C}(\mathrm{P}=0.033)$ or $10^{\circ} \mathrm{C}(\mathrm{P}=0.014)$ (Fig. 3B).

284 In slurry samples with added ammonia, the concentration of $E$. coli was already below $10 \mathrm{CFU} \mathrm{ml}^{-1}$ at day 2 285 and at $20^{\circ} \mathrm{C}$ reduced to below the detection limit within 6 days (Fig. 3A). In contrast, $12.2 \pm 2.6$ CFU E. coli $286 \mathrm{ml}^{-1}$ was detachable at day 14 in raw slurry incubated at $20^{\circ} \mathrm{C}$ (Fig. 3B), corresponding to $91.8 \%$ fewer E. coli 287 in slurry added ammonia. The estimated mean decimal reduction time $\left(T_{90}\right)$ for $E$. coli when disregarding

This article is protected by copyright. All rights reserved 
288 the temperature in raw slurry and slurry with added ammonia was 25.8 days and 9.8 days, respectively, 289 with less reduction in the raw slurry.

290 A negative correlation was observed between the uncharged $\mathrm{NH}_{3}$ concentration in slurry and $E$. coli $(r=-$ $2910.70)$ (Fig. 4A), while the correlation between uncharged $\mathrm{NH}_{3}$ and enterococci was weak $(r=0.36)$ (Fig. 4B). 292 Moreover, the correlation between enterococci and E. coli was weak ( $r=0.39)$ (data not shown).

\section{4. DISCUSSION}

294 The reached ammonia levels of the material was $71.6 \pm 5.1,88.0 \pm 2.3$ and $121.0 \pm 1.5 \mathrm{mmol} \mathrm{l}^{-1}$ at 4,10 and $29520^{\circ} \mathrm{C}$, which is higher than expected. This is due to the changing buffer capacity of the slurry in relation to 296 the temperature changing the effect on $\mathrm{pH}$ by the added ammonia.

\section{$297 \quad 4.1$ Cryptosporidium oocysts}

298 We showed that the addition of ammonia (approx. $60 \mathrm{mmol} \mathrm{I}^{-1}$ ) to cattle slurry significantly affected the 299 inactivation of $C$. parvum oocysts within 14 days of exposure resulting in $62.0 \%$ higher inactivation of non300 viable oocysts (DAPI+ $\mathrm{PI}+$ ) compared with untreated raw slurry.

301 This loss of oocyst viability due to increased ammonia concentration in the slurry agrees with results from 302 other studies (Fayer et al., 1996; Jenkins et al., 1998; Reinoso et al., 2008), and confirms the vulnerability of 303 the otherwise very robust Cryptosporidium oocysts to ammonia. For example, ammonia concentration and 304 the number of inactivated oocysts correlate in Hank's balanced salt solution (HBSS) (Reinoso et al., 2008) 305 and distilled water with an estimated 17.8 days to reach $99.9 \%$ inactivation at $30 \mathrm{mmol} \mathrm{I}^{-1} \mathrm{NH}_{3}$ and 10.2 306 days at $60 \mathrm{mmol} \mathrm{I}^{-1} \mathrm{NH}_{3}$ in distilled water (Jenkins et al., 1998). However, in our study, an estimated 307 proportion of $40.4 \%$ non-viable $(\mathrm{DAPI}+\mathrm{PI}+)$ C. parvum oocysts was present in the slurry with added 308 ammonia (mean concentration $95.3 \pm 4.54 \mathrm{mmol} \mathrm{I}^{-1}$ ammonia) at day 14 . This result was unexpected as

309 Jenkins et al. (1998) reported an estimated 8.1 days to reach 99.9\% oocyst inactivation in distilled water 310 when exposed to $104 \mathrm{mmol} \mathrm{I}^{-1}$ ammonia at $24^{\circ} \mathrm{C}$. However, manure is a more complex matter than a simple 311 aqueous ammonia solution and can differ substantially in composition due to animal species, age and diet 312 of the animals (Fayer, 1994), and therefore also harder to predict the end $\mathrm{pH}$ and thereby the 313 concentration of uncharged ammonia (Kohn et al., 2017). Furthermore, stressors such as organic matter in 314 slurry may seemingly influence oocyst viability, complicating the attempts to predict survival. The organic 315 matter also seems to act as a protector towards the inactivation effect of ammonia by providing micro316 environment with lower concentration of uncharged ammonia (Kohn et al., 2017). Ammonia is only toxic in 317 its uncharged form $\left(\mathrm{NH}_{3}\right)$, while the ammonium ion $\left(\mathrm{NH}_{4}{ }^{+}\right)$is harmless to most microorganisms (Warren, 318 1962). The mechanisms of ammonia on the survival of Cryptosporidium spp. is still unclear. There is several This article is protected by copyright. All rights reserved 
319 explanations for the effect upon cell inactivation. As all cells with active respiration, gasses needs to be 320 transferred over the cell membrane. Ammonia is a small molecule (kinetic diameter $260 \mathrm{pm}$ ) comparable to 321 water $(265 \mathrm{pm})$, in comparison to the larger $\mathrm{O}_{2}(346 \mathrm{pm})$ and is therefore expected to easily get into the 322 cells through existing pores without active transport. Most organisms maintain a stable internal cell $\mathrm{pH}$ of 323 about 7.4-7.9, but can survive over a larger external pH range of 5.5-9 (Padan et al., 2005). High ammonia 324 concentrations in the media leads to increase cellular ammonia concentrations as well due to basic 325 chemical forces. To decrease the internal $\mathrm{pH}, \mathrm{H}+$ needs to be imported via cation/proton antiporters in 326 exchange for sodium or potassium. This is an energy consuming action that the cell can continue for a set 327 time, giving a lag in the reduction. When reaching an increased cellular ammonia concentration, 328 uncompensated it leads to changes in the intracellular $\mathrm{pH}$ and followed by stress such as disturbances of 329 the electrochemical gradient and inhibition of enzymatic reactions (Martinelle and Haggstrom, 1993). The 330 faecal material might provide the oocysts some protection from direct exposure to the chemical activity of 331 uncharged $\mathrm{NH}_{3}$, while oocysts stored in water will be directly exposed to the toxic effect of ammonia. 332 Mucopolysaccharides in faeces may be incorporated into the oocyst wall to provide the oocysts with 333 protection from environmental stress as suggested by Robertson et al. (1992). This hypothesis is supported 334 by Kearney et al. (1993), who proposed that high levels of organic matter might be conducive to pathogen 335 adherence, initiating increased survival. Unfortunately, our study did not include oocysts stored in water 336 and added ammonia, preventing us from concluding whether slurry protects oocysts from the inactivating 337 effect of ammonia.

338 Our results is in line with a previous study that found approx. 60\% viable Cryptosporidium oocysts at day 94 339 in slurry generated by breeding pigs during summer and stored at ambient temperature without additional 340 ammonia added (Hutchison et al., 2005b). Robertson et al. (1992) observed that at $4{ }^{\circ} \mathrm{C}$, an oocyst fraction 341 in stool samples from individuals with cryptosporidiosis remained viable for at least 178 days, while others 342 found that oocysts remained infective to mice for 10 weeks when stored in faeces at $10{ }^{\circ} \mathrm{C}$ ( $\mathrm{Li}$ et al., 2010 ; 343 Olson et al., 1999). However, contradictory results have been presented in other studies demonstrating 344 faster oocyst degradation in faeces compared with water (Jenkins et al., 1999; Olson et al., 1999), and 345 similar survival rates for oocysts placed in containers buried in cow faeces or in laboratory-grade water 346 (Robertson et al., 1992). The discrepancies in survival rates between studies might be explained by species 347 and isolate variations in ability of the oocysts to withstand environmental pressures or by differences in the 348 methods used to determine oocysts inactivation.

349 The proportion of non-variable oocyst were unaffected when stored in buffers at $\mathrm{pH} 7$ and 9, indicating that 350 within the examined $\mathrm{pH}$ range, the $\mathrm{pH}$ is not important for oocyst inactivation. This is in agreement with 351 results obtained by Jenkins et al. (1998), who found minimal changes in the frequency of DAPI+ PI+ (nonThis article is protected by copyright. All rights reserved 
viable) oocysts at pH between 7 and 11. Jenkins et al. (1998) hypothesize that the inability of pH alone to 353 inactive Cryptosporidium oocysts is because the charged components of $\mathrm{pH}\left(\mathrm{H}^{+}\right.$and $\left.\mathrm{OH}^{-}\right)$remain external to 354 the oocyst wall. Nevertheless, other studies have shown that high and low pH can affect oocyst viability 355 significantly (Reinoso et al., 2008; Robertson et al., 1992). A recent study by Senecal et al. (2018) looking at 356 the effect of $\mathrm{pH}$ on Ascaris suum showed that there were actually no effect upon the viability over 180 days 357 at $\mathrm{pH}$ up to $>12$. This indicates that effects reported from inactivation of parasites with elevated $\mathrm{pH}$ often 358 have been due to combined effect of $\mathrm{pH}$ and supporting molecules such as ammonia.

359 In our study, changes in the proportion of non-viable oocysts over time were unaffected by incubation 360 temperature in both ammonia treated slurry and raw slurry. This lack of any effect of temperature was 361 unexpected because stressors such as temperature are widely reported to be particularly effective in 362 influencing oocyst inactivation (Fayer, 1994; Fayer and Nerad, 1996; Li et al., 2010; Olson et al., 1999; 363 Pokorny et al., 2002). For example, Pokorny et al. (2002) showed decreased C. parvum infectivity in a 364 mouse model when the temperature of river water increased from $4{ }^{\circ} \mathrm{C}$ to $23{ }^{\circ} \mathrm{C}$. Additionally, the 365 incubation temperature usually affects the ammonium-ammonia equilibrium, initiating a rise in uncharged $366 \mathrm{NH}_{3}$ concentration with increasing temperature (Christensen and Sommer, 2013), as observed in our study 367 with raw slurry. This theoretically enhances the effect of temperature, because increased uncharged $\mathrm{NH}_{3}$ 368 concentration can escalate oocyst inactivation (Jenkins et al., 1998). However, aq. ammonia added to the 369 slurry in this study was adjusted to achieve the same uncharged $\mathrm{NH}_{3}$ concentration regardless of 370 temperature, in order to examine whether the effectiveness of ammonia changes with temperatures as 371 reported elsewhere (Jenkins et al., 1998; Vinnerås et al., 2008). No increased effect of ammonia with 372 changing the temperature on oocyst inactivation was observed. This contradicts results obtained by Jenkins 373 et al. (1998), who found higher oocyst inactivation in distilled water at temperatures around $25{ }^{\circ} \mathrm{C}$ 374 compared with $4{ }^{\circ} \mathrm{C}$ when exposed to the same $\mathrm{NH}_{3}$ concentration. Fidjeland et al. (2013) reported a similar 375 trend for Ascaris suum egg viability; at equal $\mathrm{NH}_{3}$ concentration, the time to reach a 3 log reduction in 376 faecal sludge was shorter at higher temperatures. The proposed reason for increased effect of ammonia 377 with increased temperature are related to the increase of the permeability of the outer lipid layers of the 378 cells in combination to increased chemical mobility at increased temperatures (Kohn et al., 2017). For 379 Ascaris spp. a drop in ammonia sensitivity has been noticed when decreasing the temperature from $20^{\circ} \mathrm{C}$ 380 to $10{ }^{\circ} \mathrm{C}$, this was assumed to be caused of a change in permeability (Fidjeland et al., 2015), while for 381 Cryptosporidium oocysts it appears to be at a higher temperature.

This article is protected by copyright. All rights reserved 


\subsection{Bacterial indicators}

383 Addition of aq. ammonia to the cattle slurry in our study significantly affected the numbers of indigenous $E$.

384 coli and enterococci. In particular, E. coli appeared sensitive to treatment, as evidenced by a reduction 385 below the detection limit of $1 \mathrm{CFU} \mathrm{ml}^{-1}$ within 6 days. In contrast, in raw slurry $12.2 \pm 2.6 \mathrm{CFU} \mathrm{E}$. coli ml-1 386 remained culturable at day 14 , with a mean estimated decimal reduction time $\left(T_{90}\right)$ of 25.8 days. Similar $T_{90}$ 387 values have been reported for indigenous $E$. coli in non-aerated cattle slurry at $7{ }^{\circ} \mathrm{C}$ and $20^{\circ} \mathrm{C}$ (Munch et al., 388 1987). Moreover, Kudva, Blanch and Hovde (1998) reported a 3.0-3.5 log reduction over 30 days at $4{ }^{\circ} \mathrm{C}$ in 389 an E. coli O157:H7 strain spiked to bovine slurry, while (McGee et al., 2001) reported an approximate 3.5$3905.5 \log$ reduction of E. coli $\mathrm{O} 157: \mathrm{H} 7$ over 12 weeks at $10{ }^{\circ} \mathrm{C}$ in cattle slurry. In contrast, a rapid E. coli 391 0157:H7 decline from $1.2 \times 10^{8} \mathrm{CFU} \mathrm{ml}^{-1}$ to undetectable numbers was observed within 9 days when spiked 392 to cattle slurry and stored at $18{ }^{\circ} \mathrm{C}$ (Maule, 1997). However, in contrast to the present study, slurry samples 393 were aerated during storage, which seemingly resulted in faster pathogen inactivation (Munch et al., 1987). 394 These data indicate a tendency for longer survival of indigenous bacteria compared with spiked bacterial 395 strains, possibly due to adaptations to the environmental conditions in the slurry. Consequently, results 396 based solely on spiked bacterial strains might underestimate the decimal reduction rate. Additionally the 397 above-mentioned studies do not keep track of mechanisms for inactivation, i.e. $\mathrm{pH}$ and uncharged 398 ammonia that heavily affect the inactivation rate of E.coli.

399 Addition of aq. ammonia to slurry reduced survival of enterococci less than E. coli. These findings agree 400 with those of earlier studies in which enterococci displayed lower ammonia sensitivity, were more heat401 resistant, and survived longer than E. coli, Salmonella spp., and several other bacterial pathogens (Bitton, 402 2011; Nordin et al., 2013, 2009; Ottoson et al., 2008b; Vinnerås et al., 2008; Watcharasukarn et al., 2009). 403 Enterococci are Gram-positive bacteria whose cell wall offers more resistance to mesophilic temperature, 404 disinfection, and desiccation compared with Gram-negative bacteria such as E. coli (Bitton, 2011; Ottoson 405 et al., 2008b; WHO, 2004). In a field study of human urine with an ammonia concentration of $4.2 \mathrm{~g} \mathrm{I}^{-1}$, 406 stored at $19-31{ }^{\circ} \mathrm{C}$, E. coli was reduced more rapidly ( $\mathrm{T}_{90}=0.1$ day) than enterococci $\left(\mathrm{T}_{90}=7.6-7.7\right.$ days $)$ 407 (Nordin et al., 2013). Similarly to E. coli, enterococci added to urine, and sewage- and faecal sludge samples 408 appeared more sensitive to ammonia than indigenous enterococci (Fidjeland et al., 2013a, 2013b; Nordin et 409 al., 2013). In addition, some studies have demonstrated that enterococci exposed to low concentrations of 410 uncharged $\mathrm{NH}_{3}$ display a biphasic reduction where the length of the lag phase depends on incubation 411 temperature (Fidjeland et al., 2013b, 2013a). An approximate 20-day lag phase for enterococci was 412 observed at $14{ }^{\circ} \mathrm{C}$ in bovine manure with $2 \%$ urea added, while the linear die-off phase was absent at $4{ }^{\circ} \mathrm{C}$ 413 (Ottoson et al., 2008a). In the present study, enterococci lacked a biphasic die-off rate both in raw slurry This article is protected by copyright. All rights reserved 
414 and in slurry with added ammonia, probably due to the short duration of the study (14 days). The decimal 415 reduction rate was estimated based on a linear regression model, with risks overestimating the rate.

416 In general, we did not observe any temperature dependent major reductions of $E$. coli and enterococci over 417 time. However, enterococci in slurry with added ammonia and E. coli in raw slurry incubated at $20^{\circ} \mathrm{C}$ 418 required a shorter storage time to achieve a $1 \log$ reduction compared with $4{ }^{\circ} \mathrm{C}$ and $10{ }^{\circ} \mathrm{C}$. This was 419 probably attributable to the significant rise in uncharged $\mathrm{NH}_{3}$ concentration with higher temperature (20 $420{ }^{\circ} \mathrm{C}$ ) (Christensen and Sommer, 2013) measured in raw slurry and slurry with added ammonia, rather than 421 being solely a temperature effect. Similarly, Fidjeland et al. (2013b) observed corresponding die-off for 422 enterococci treated with $0.5-2.0 \%$ urea in sewage sludge at similar temperatures within the first 14 days of 423 their study. As described for Cryptosporidium oocysts, a significant effect of temperature on bacteria die-off 424 rate has been reported (Kudva et al., 1998; Ottoson et al., 2008a).

\subsection{Conclusion}

426 Overall, addition of ammonia to cattle slurry significantly increased the inactivation of pathogenic $C$. 427 parvum oocysts, and reduced the numbers of $E$. coli and enterococci compared with raw, untreated slurry. 428 However, only E. coli was reduced to below the detection limit within the study period of 14 days, while 7.2 $429 \times 10^{3} \mathrm{CFU} \mathrm{ml}^{-1}$ enterococci were still present at day 14 in ammonia treated slurry. Interestingly, the 430 effectiveness of ammonia in inactivating microorganisms was not noted with increasing temperature. To be 431 able to notice this for E.coli a higher sampling interval would be required and for the enterococcus and 432 Cryptosporidium oocysts a longer sampling period would be required.

433 Our findings indicate that adding ammonia to slurry prior to application to agricultural land could be used 434 to reduce pathogen concentrations in slurry lowering the contamination of water and food sources with 435 the zoonotic Cryptosporidium. However, the ammonia concentration tested where not high enough for all 436 Cryptosporidium oocysts and enterococci to be inactivated within the study period to eliminate the public 437 health risk. Hence, further experimental work is warranted to explore the full potential of ammonia 438 treatment and to determine ammonia concentration and exposure time needed to abolish the risk of 439 Cryptosporidium transmission from cattle slurry. It should also be investigated whether ammonia treatment 440 of animal slurries increases the risk of ammonia loss to the atmosphere during slurry storage, because this 441 would have a highly undesirable impact on the environment; ammonia emissions from animal production 442 systems are being restricted in many countries through strict environmental regulations (Sommer et al., 443 2013). Furthermore, also potential impacts of the ammonia treatment on the risk of discharge of 444 ammonia/ammonium to waterways through potential runoff needs to be investigated, though the risk will 445 most likely be minimal when soils are not overloaded with slurry in excess of crop nitrogen demand.

This article is protected by copyright. All rights reserved 


\section{Acknowledgement}

447 We thank The National Veterinary Institute, Technical University of Denmark, for the use of their laboratory 448 facilities, and Tobias Boel Petersen and Gitte Petersen for assistance in the laboratory.

449 Funding: This work was supported by a grant from the PATHOS Project funded by the Strategic Research 450 Council of Denmark [grant numbers ENV2104-07-0015]; The Ph.D. fellowship of Heidi Huus Petersen was 451 jointly financed by the PATHOS project and Faculty of Health and Medical Sciences, University of 452 Copenhagen and its Ph.D. Research School, RECETO.

\section{Conflict of interest}

$454 \quad$ No conflict of interest declared.

\section{Ethics approval and consent to participate}

456 This study did not require official or institutional ethical approval.

This article is protected by copyright. All rights reserved 


\section{References}

458 Abu-Ashour, J., Lee, H., 2000. Transport of bacteria on sloping soil surfaces by runoff. Environ. Toxicol. 15, 149-153. https://doi.org/10.1002/(SICI)1522-7278(2000)15:2<149::AID-TOX11>3.0.CO;2-O

460 Bitton, G., 2011. Wastewater Microbiology. Wiley-Blackwell, Hoboken, NJ, USA.

461 Bodley-Tickell, A.T., Kitchen, S.E., Sturdee, A.P., 2002. Occurrence of Crypstosporidium in agricultural surface waters during an annual farming cycle in lowland UK. Water Res. 36, 1880-1886. https://doi.org/10.1016/S0043-1354(01)00398-0

464 Christensen, M.L., Sommer, S.G., 2013. Manure Characterisation and Inorganic Chemistry, in: Sommer, S.G., 465 Christensen, M.L., Schmidt, T., Jensen, L.S. (Eds.), Animal Manure Recycling - Treatment and Management. John Wiley \& Sons Ltd, Ltd, Chichester, UK, pp. 41-65.

Clark, C.G., Price, L., Ahmed, R., Woodward, D.L., Melito, P.L., Rodgers, F.G., Jamieson, F., Ciebin, B., Li, A., Ellis, A., 2003. Characterization of waterborne outbreak-associated Campylobacter jejuni, Walkerton, Ontario. Emerg. Infect. Dis. 9, 1232-1241. https://doi.org/10.3201/eid0910.020584

Fayer, R., 1994. Effect of high temperature on infectivity of Cryptosporidium parvum oocysts in water. Appl. Environ. Microbiol. 60, 2732-2735. https://doi.org/10.1128/AEM.60.8.2732-2735.1994

Fayer, R., Graczyk, T.K., Cranfield, M.R., Trout, J.M., 1996. Gaseous disinfection of Cryptosporidium parvum oocysts. Appl. Environ. Microbiol. 62, 3908-3909. https://doi.org/10.1128/AEM.62.10.3908-

475 Fayer, R., Nerad, T., 1996. Effects of low temperatures on viability of Cryptosporidium parvum oocysts. Appl. Environ. Microbiol. 62, 1431-1433. https://doi.org/10.1128/AEM.62.4.1431-1433.1996

477 Fidjeland, J., Lalander, C., Jonsson, H., Vinnerås, B., 2013a. Ammonia sanitisation of sewage sludge using urea. Water Sci. Technol. 68, 1866-1872. https://doi.org/10.2166/wst.2013.443

479 Fidjeland, J., Magri, M.E., Jönsson, H., Albihn, A., Vinnerås, B., 2013b. The potential for self-sanitisation of 480 faecal sludge by intrinsic ammonia. Water Res. 47, 6014-6023. 481 https://doi.org/10.1016/j.watres.2013.07.024

482 Fidjeland, J., Nordin, A., Pecson, B.M., Nelson, K.L., Vinnerås, B., 2015. Modeling the inactivation of Ascaris 483 eggs as a function of ammonia concentration and temperature. Water Res. 83, 153-160. https://doi.org/10.1016/j.watres.2015.06.030

485 Forslund, A., Markussen, B., Toenner-Klank, L., Bech, T.B., Jacobsen, O.S., Dalsgaard, A., 2011. Leaching of 486 Cryptosporidium parvum oocysts, Escherichia coli, and a Salmonella enterica serovar Typhimurium This article is protected by copyright. All rights reserved 
bacteriophage through intact soil cores following surface application and injection of slurry. Appl. Environ. Microbiol. 77, 8129-8138. https://doi.org/10.1128/AEM.05675-11

489 Harris, J.R., Petry, F., 1999. Cryptosporidium parvum: Structural components of the oocyst wall. J. Parasitol. $490 \quad 85,839$. https://doi.org/10.2307/3285819

491 Henriksen, S.A., Pohlenz, J.F.L., 1981. Staining of Cryptosporidia by a modified Ziehl-Neelsen technique. $492 \quad$ Acta Vet. Scand. 22, 594-596.

493 Himathongkham, S., Riemann, H., 1999. Destruction of Salmonella typhimurium, Escherichia coli O157:H7 494 and Listeria monocytogenes in chicken manure by drying and/or gassing with ammonia. FEMS 495 Microbiol. Lett. 171, 179-182. https://doi.org/10.1111/j.1574-6968.1999.tb13430.x

496 Hrudey, S.E., Payment, P., Huck, P.M., Gillham, R.W., Hrudey, E.J., 2003. A fatal waterborne disease 497 epidemic in Walkerton, Ontario: comparison with other waterborne outbreaks in the developed 498 world. Water Sci. Technol. 47, 7-14. https://doi.org/10.2166/wst.2003.0146

499 Hutchison, M.L., Walters, L.D., Avery, S.M., Munro, F., Moore, A., 2005a. Analyses of livestock production, $500 \quad$ waste storage, and pathogen levels and prevalences in farm manures. Appl. Environ. Microbiol. 71, 501 1231-1236. https://doi.org/10.1128/AEM.71.3.1231-1236.2005

502 Hutchison, M.L., Walters, L.D., Moore, A., Avery, S.M., 2005b. Declines of zoonotic agents in liquid livestock 503 wastes stored in batches on-farm. J. Appl. Microbiol. 99, 58-65. https://doi.org/10.1111/j.1365$504 \quad 2672.2005 .02585 . x$

505 Islam, M., Morgan, J., Doyle, M.P., Phatak, S.C., Millner, P., Jiang, X., 2004. Fate of Salmonella enterica 506 Serovar Typhimurium on carrots and radishes grown in fields treated with contaminated manure 507 composts or irrigation water. Appl. Environ. Microbiol. 70, $2497-2502$. $508 \quad$ https://doi.org/10.1128/AEM.70.4.2497-2502.2004

509 Jenkins, M.B., Bowman, D.D., Ghiorse, W.C., 1998. Inactivation of Cryptosporidium parvum oocysts by 510 ammonia. Appl. Environ. Microbiol. 64, 784-788. https://doi.org/10.1128/AEM.64.2.784-788.1998

511 Jenkins, M.B., Walker, M.J., Bowman, D.D., Anthony, L.C., Ghiorse, W.C., 1999. Use of a sentinel system for 512 field measurements of Cryptosporidium parvum oocyst inactivation in soil and animal waste. Appl. 513 Environ. Microbiol. 65, 1998-2005. https://doi.org/10.1128/AEM.65.5.1998-2005.1999

514 Kearney, T.E., Larkin, M.J., Levett, P.N., 1993. The effect of slurry storage and anaerobic digestion on 515 survival of pathogenic bacteria. J. Appl. Bacteriol. 74, 86-93. https://doi.org/10.1111/j.1365516 2672.1993.tb03000.x

This article is protected by copyright. All rights reserved 
Kohn, T., Decrey, L., Vinnerås, B., 2017. Chemical Disinfectants, in: Rose, J.B., Jiménez-Cisneros, B., Haas, C. (Eds.), Global Water Pathogen Project. Global Water Pathogens Projekct.

519 Korich, D.G., Mead, J.R., Madore, M.S., Sinclair, N.A., Sterling, C.R., 1990. Effects of ozone, chlorine dioxide, 520 chlorine, and monochloramine on Cryptosporidium parvum oocyst viability. Appl. Environ. Microbiol. 56, 1423-1428. https://doi.org/10.1128/AEM.56.5.1423-1428.1990

522 Kudva, I.T., Blanch, K., Hovde, C.J., 1998. Analysis of Escherichia coli O157:H7 survival in ovine or bovine 523 manure and manure slurry. Appl. Environ. Microbiol. 64, 3166-3174. 524 https://doi.org/10.1128/AEM.64.9.3166-3174.1998

525 Langkjær, R.B., Vigre, H., Enemark, H.L., Maddox-Hyttel, C., 2007. Molecular and phylogenetic 526 characterization of Cryptosporidium and Giardia from pigs and cattle in Denmark. Parasitology 134, 339. https://doi.org/10.1017/S0031182006001533

528 Li, X., Atwill, E.R., Dunbar, L.A., Tate, K.W., 2010. Effect of daily temperature fluctuation during the cool 529 season on the infectivity of Cryptosporidium parvum. Appl. Environ. Microbiol. 76, 989-993. 530 https://doi.org/10.1128/AEM.02103-09

531 Martinelle, K., Haggstrom, L., 1993. Mechanisms of ammonia and ammonium ion toxicity in animal-cells 532 transport across cell-membranes. J. Biotechnol. 30, 339-350. https://doi.org/10.1016/0168$533 \quad 1656(93) 90148-G$

534 Maule, A., 1997. Survival of the verotoxigenic strain E. coli O157:H7 in laboratory-scale microcosms, in: Kay, 535 D., Fricker, C.R. (Eds.), Coliforms and E. Coli: Problem or Solution? Athenaeum Press Ltd, Gateshead, $536 \quad$ UK, pp. 61-65.

537 Mawdsley, J.L., Brooks, A.E., Merry, R.J., 1996. Movement of the protozoan pathogen Cryptosporidium 538 parvum through three contrasting soil types. Biol. Fertil. Soils 21, 30-36. 539 https://doi.org/10.1007/BF00335990

540 McGee, P., Bolton, D.J., Sheridan, J.J., Earley, B., Leonard, N., 2001. The survival of Escherichia coli O157:H7 541 in slurry from cattle fed different diets. Lett. Appl. Microbiol. 32, $152-155$. 542 https://doi.org/10.1046/j.1472-765x.2001.00877.x

543 Mendez, J.M., Jimenez, B., Maya, C., 2004. Disinfection kinetics of pathogens in physicochemical sludge 544 treated with ammonia. Water Sci. Technol. 50, 67-74. https://doi.org/10.2166/wst.2004.0536

545 Munch, B., Larsen, H.E., Aalbaek, B., 1987. Experimental studies on the survival of pathogenic and indicator 546 bacteria in aerated and non-aerated cattle and pig slurry. Biol. Wastes 22, 49-65.

This article is protected by copyright. All rights reserved 
547 Nordin, A., 2010. Ammonia sanitation of human excreta - treatment technology for production of fertilizer. 548 Doctoral thesis. Swedish Univ. Agric. Sci. Uppsala, Sweden.

549 Nordin, A., Niwagaba, C., Jönsson, H., Vinnerås, B., 2013. Pathogen and indicator inactivation in source550 separated human urine heated by the sun. J. Water Sanit. Hyg. Dev. 3, 181-188. 551 https://doi.org/10.2166/washdev.2013.174

552 Nordin, A., Nyberg, K., Vinnerås, B., 2009. Inactivation of Ascaris eggs in source-separated urine and feces 553 by ammonia at ambient temperatures. Appl. Environ. Microbiol. 75, 662-667. 554 https://doi.org/10.1128/AEM.01250-08

555 Okhuysen, P.C., Chappell, C.L., Crabb, J.H., Sterling, C.R., DuPont, H.L., 1999. Virulence of three distinct 556 Cryptosporidium parvum isolates for healthy adults. J. Infect. Dis. 180, 1275-1281. https://doi.org/10.1086/315033

558 Olson, M.E., Goh, J., Phillips, M., Guselle, N., McAllister, T.A., 1999. Giardia cyst and Cryptosporidium oocyst 559 survival in water, soil, and cattle feces. J. Environ. Qual. 28, 1991. $560 \quad$ https://doi.org/10.2134/jeq1999.00472425002800060040x

561 Ong, C., Moorehead, W., Ross, A., Isaac-Renton, J., 1996. Studies of Giardia spp. and Cryptosporidium spp. 562 in two adjacent watersheds. Appl. Environ. Microbiol. 62, 2798-2805. 563 https://doi.org/10.1128/AEM.62.8.2798-2805.1996

564 Ottoson, J., Nordin, A., von Rosen, D., Vinnerås, B., 2008a. Salmonella reduction in manure by the addition 565 of urea and ammonia. Bioresour. Technol. 99, 1610-1615. 566 https://doi.org/10.1016/j.biortech.2007.04.009

567 Ottoson, J., Schnürer, A., Vinnerås, B., 2008b. In situ ammonia production as a sanitation agent during 568 anaerobic digestion at mesophilic temperature. Lett. Appl. Microbiol. 46, 325-330. $569 \quad$ https://doi.org/10.1111/j.1472-765X.2007.02317.x

570 Padan, E., Bibi, E., Ito, M., Krulwich, T.A., 2005. Alkaline pH homeostasis in bacteria: New insights. Biochim. 571 Biophys. Acta - Biomembr. 1717, 67-88. https://doi.org/10.1016/j.bbamem.2005.09.010

572 Pelly, H., Cormican, M., O’Donovan, D., Chalmers, R., Hanahoe, B., Cloughley, R., McKeown, P., Corbett573 Feeney, G., 2007. A large outbreak of cryptosporidiosis in western Ireland linked to public water 574 supply: a preliminary report. Wkly. releases 12 , 3187. https://doi.org/10.2807/esw.12.18.03187-en

575 Petersen, H.H., Enemark, H.L., Olsen, A., Amin, M.G., Dalsgaard, A., 2012. Transport of Cryptosporidium 576 parvum oocysts in soil columns following applications of raw and separated liquid slurries. Appl.

This article is protected by copyright. All rights reserved 
578 Pokorny, N.J., Weir, S.C., Carreno, R.A., Trevors, J.T., Lee, H., 2002. Influence of temperature on 579 Cryptosporidium parvum oocyst infectivity in river water samples as detected by tissue culture assay. 580 J. Parasitol. 88, 641. https://doi.org/10.2307/3285469

581 Reinoso, R., Becares, E., Smith, H. V, 2008. Effect of various environmental factors on the viability of 582 Cryptosporidium parvum oocysts. J. Appl. Microbiol. 104, 980-986. https://doi.org/10.1111/j.1365$583 \quad 2672.2007 .03620 . x$

584 Robertson, L.J., Campbell, A.T., Smith, H. V, 1992. Survival of Cryptosporidium parvum oocysts under 585 various environmental pressures. Appl. Environ. Microbiol. 58, 3494-3500. 586 https://doi.org/10.1128/AEM.58.11.3494-3500.1992

587 Senecal, J., Nordin, A., Simha, P., Vinnerås, B., 2018. Hygiene aspect of treating human urine by alkaline 588 dehydration. Water Res. 144, 474-481. https://doi.org/10.1016/j.watres.2018.07.030

589 Senecal, J., Nordin, A., Vinnerås, B., 2020. Fate of Ascaris at various pH, temperature and moisture levels. J. 590 Water Health 18, 375-382. https://doi.org/10.2166/wh.2020.264

591 Shields, J.M., Hill, V.R., Arrowood, M.J., Beach, M.J., 2008. Inactivation of Cryptosporidium parvum under 592 chlorinated recreational water conditions. J. Water Health 6, 513-520. 593 https://doi.org/10.2166/wh.2008.068

594 Sommer, S.G., Christensen, M.L., Schmidt, T., Jensen, L.S., 2013. Animal Manure Recycling - Treatment and 595 Management. John Wiley \& Sons Ltd, Chichester, UK.

596 Thurston-Enriquez, J.A., Gilley, J.E., Eghball, B., 2005. Microbial quality of runoff following land application 597 of cattle manure and swine slurry. J. Water Health 3, 157-171. https://doi.org/10.2166/wh.2005.0015 598 Venczel, L. V, Arrowood, M., Hurd, M., Sobsey, M.D., 1997. Inactivation of Cryptosporidium parvum oocysts 599 and Clostridium perfringens spores by a mixed-oxidant disinfectant and by free chlorine. Appl. $600 \quad$ Environ. Microbiol. 63, 4625.

601 Vinnerås, B., 2013. Sanitation and Hygiene in Manure Management, in: Sommer ML Schmidt, T Jensen,LS, 602 S.G.C. (Ed.), Animal Manure Recycling - Treatment and Management. John Wiley \& Sons Ltd, 603 Chichester, UK, p. 104.

604 Vinnerås, B., Nordin, A., Niwagaba, C., Nyberg, K., 2008. Inactivation of bacteria and viruses in human urine 605 depending on temperature and dilution rate. Water Res. 42, 4067-4074. 606 https://doi.org/10.1016/j.watres.2008.06.014

This article is protected by copyright. All rights reserved 
Table 1. Properties of the cattle slurry used in the experiment

Parameter measured

$\mathrm{pH}$

Electric conductivity (mS)

Dry matter (\% of wet weight)

Total ammoniacal nitrogen:

Oocysts $\left.\right|^{-1}$

E. coli (CFU ml-1)

Enterococci (CFU ml-1)
Mean \pm S.D.

$8.48 \pm 0.08$

$13.8 \pm 1.7$

$3.55 \pm 0.03$

(TAN, $\mathrm{mg} \mathrm{l}^{-1}$ )

$2050 \pm 256$

$\left(\mathrm{mmol} \mathrm{l}^{-1}\right)$

$145 \pm 10$

$8 \pm 1.20^{a}$

$68 \pm 28$

$1.6 \times 10^{4} \pm 2.5 \times 10^{3}$

aAll oocysts found in the slurry prior to spiking were categorized as DAPI+ $\mathrm{PI}+$. 
Table 2. Schematic overview of the experimental design. A " $x$ " means that sampling has been done this day, while "”" indicate no sampling.

\begin{tabular}{|c|c|c|c|c|c|c|c|c|c|c|c|c|}
\hline \multirow{2}{*}{$\begin{array}{l}\text { Tube size and content } \\
\text { (n) }\end{array}$} & \multirow[b]{2}{*}{ Treatment (n) } & \multirow[b]{2}{*}{ Analysis } & \multirow{2}{*}{$\begin{array}{l}\text { Slurry volum } \\
\text { used (g) }\end{array}$} & \multirow[b]{2}{*}{$\mathbf{n}$} & \multicolumn{8}{|c|}{ Sampling day for tubes incubated at 4,10 or $20^{\circ} \mathrm{C}^{a}$} \\
\hline & & & & & 0 & 2 & 4 & 6 & 8 & 10 & 12 & 14 \\
\hline $50 \mathrm{ml}$ with $10 \mathrm{~g}$ slurry & $\mathrm{NH}_{3}(72)$ & Oocyst inactivation & 1.5 & 63 & $\div$ & $\mathrm{x}$ & $\mathrm{x}$ & $x$ & $\mathrm{x}$ & $\mathrm{x}$ & $x$ & $x$ \\
\hline \multirow[t]{5}{*}{ (144) } & & $\mathrm{pH}^{\mathrm{b}}$ & 10 & 72 & $x$ & $\mathrm{x}$ & $\mathrm{x}$ & $x$ & $\mathrm{x}$ & $x$ & $x$ & $x$ \\
\hline & & $\mathrm{NH}_{3}$ & 5 & 72 & $\mathrm{x}$ & $\mathrm{x}$ & $\mathrm{x}$ & $\mathrm{x}$ & $\mathrm{x}$ & $\mathrm{x}$ & $x$ & $\mathrm{x}$ \\
\hline & Control (72) & Oocyst inactivation & 1.5 & 63 & $\div$ & $\mathrm{x}$ & $\mathrm{x}$ & $\mathrm{x}$ & $x$ & $x$ & $\mathrm{x}$ & $\mathrm{x}$ \\
\hline & & $\mathrm{pH}^{\mathrm{b}}$ & 10 & 72 & $x$ & $\mathrm{x}$ & $\mathrm{x}$ & $\mathrm{x}$ & $\mathrm{x}$ & $\mathrm{x}$ & $x$ & $\mathrm{x}$ \\
\hline & & $\mathrm{NH}_{3}$ & 5 & 72 & $x$ & $x$ & $\mathrm{x}$ & $x$ & $\mathrm{x}$ & $x$ & $x$ & $\mathrm{x}$ \\
\hline $15 \mathrm{ml}$ with $10 \mathrm{~g}$ slurry & $\mathrm{NH}_{3}(72)$ & E. coli count & $10^{c}$ & 72 & $x$ & $\mathrm{x}$ & $\mathrm{x}$ & $x$ & $\mathrm{x}$ & $\mathrm{x}$ & $x$ & $x$ \\
\hline \multirow[t]{3}{*}{ (144) } & & Enterococci count & $10^{c}$ & 72 & $\mathrm{x}$ & $\mathrm{x}$ & $\mathrm{x}$ & $\mathrm{x}$ & $\mathrm{x}$ & $\mathrm{x}$ & $x$ & $\mathrm{x}$ \\
\hline & Control (72) & E. coli count & $10^{c}$ & 72 & $\mathrm{x}$ & $\mathrm{x}$ & $\mathrm{x}$ & $x$ & $\mathrm{x}$ & $\mathrm{x}$ & $x$ & $\mathrm{x}$ \\
\hline & & Enterococci count & $10^{c}$ & 72 & $x$ & $\mathrm{x}$ & $\mathrm{x}$ & $\mathrm{x}$ & $x$ & $\mathrm{x}$ & $\mathrm{x}$ & $\mathrm{x}$ \\
\hline
\end{tabular}

This article is protected by copyright. All rights reserved 
$50 \mathrm{ml}$ with $10 \mathrm{ml}$ buffer (18) pH=7 (9)

$\mathrm{pH}=9$ (9)
Oocyst inactivation

Oocyst inactivation
10

10
9

9 $\div$ $\div \quad \div$

$\div \quad \div$
$\div \quad \div$

a Three replicate samples each day

${ }^{\mathrm{b}}$ The slurry used for $\mathrm{pH}$ measurement was afterwards used for measuring $\mathrm{NH}_{3}$ and assessment of oocyst inactivation. c

Serial

dilution

This article is protected by copyright. All rights reserved 


\section{FIGURE LEGENDS}

Figure 1. Mean with $95 \% \mathrm{Cl}$ of A) $\mathrm{pH}$ and $\mathrm{B}$ ) calculated uncharged $\mathrm{NH}_{3}$ concentration at three temperatures in cattle slurry with added aqueous (aq.) ammonia and in raw slurry as a function of time. The $95 \% \mathrm{Cl}$ values not indicated are smaller than the symbols. The symbols represents: slurry added aq. ammonia at $4{ }^{\circ} \mathrm{C}$ (solid line, black circle); slurry added aq. ammonia at $10{ }^{\circ} \mathrm{C}$ (dashed line, white circle); slurry added aq. ammonia at $20^{\circ} \mathrm{C}$ (dotted line, grey circle); raw slurry at $4{ }^{\circ} \mathrm{C}$ (solid line, black diamond); raw slurry at $10{ }^{\circ} \mathrm{C}$ (dashed line, white diamond); raw slurry at $20^{\circ} \mathrm{C}$ (dotted line, grey diamond).

Figure 2. A) Individual plots ( $n=9$, triplicate samples for each of three temperatures) and B) Box and whiskers plot of percentage of non-viable (DAPI+ $\mathrm{PI}+$ ) Cryptosporidium parvum oocysts spiked to cattle slurry with added aqueous ammonia $(\bullet(A)$, striped $(B))$ and raw slurry $(O(A)$, white $(B))$ as a function of time, irrespective of incubation temperature.

Figure 3. Mean E. coli and enterococci concentrations (CFU ml-1) with Standard error of the mean (SEM) as a function of time in A) cattle slurry with added aqueous (aq.) ammonia and B) raw slurry at the temperatures 4 ${ }^{\circ} \mathrm{C}$ (solid line, black circle), $10{ }^{\circ} \mathrm{C}$ (dashed line, white circle) and $20^{\circ} \mathrm{C}$ (dotted line, grey circle). . SSEM values not indicated are smaller than the symbols.

Figure 4. Correlation between calculated uncharged NH3 concentration in the slurry samples and A) Escherichia coli; and B) enterococci. o: cattle slurry with added aq. ammonia; $\bullet$ : raw slurry. Dashed line: linear regression line with correlation coefficients $(r)=-0.80$ for $C$. parvum oocysts, -0.70 for $E$. coli, and -0.36 for enterococci. 
A

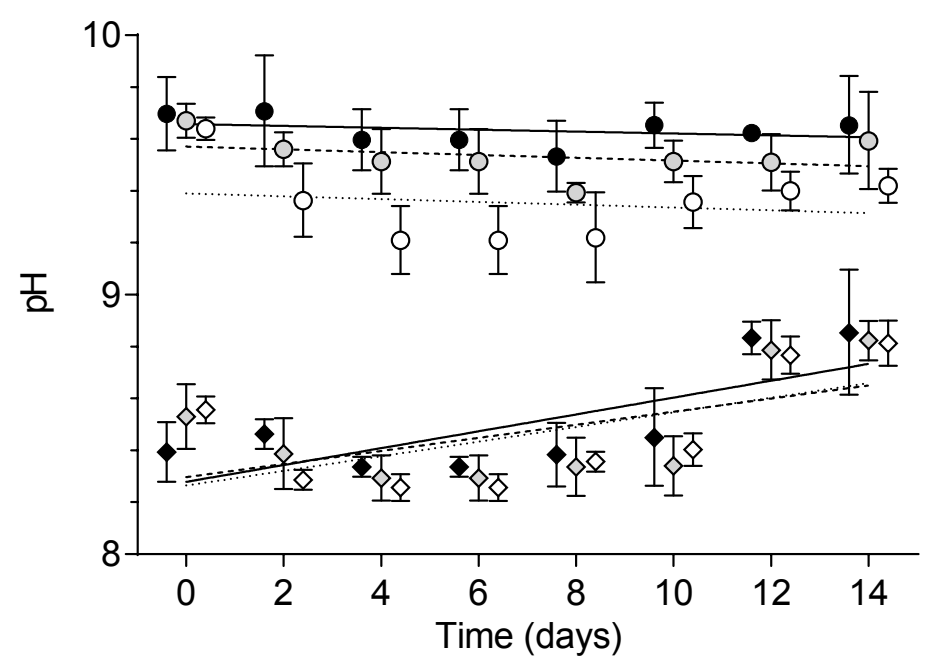

B

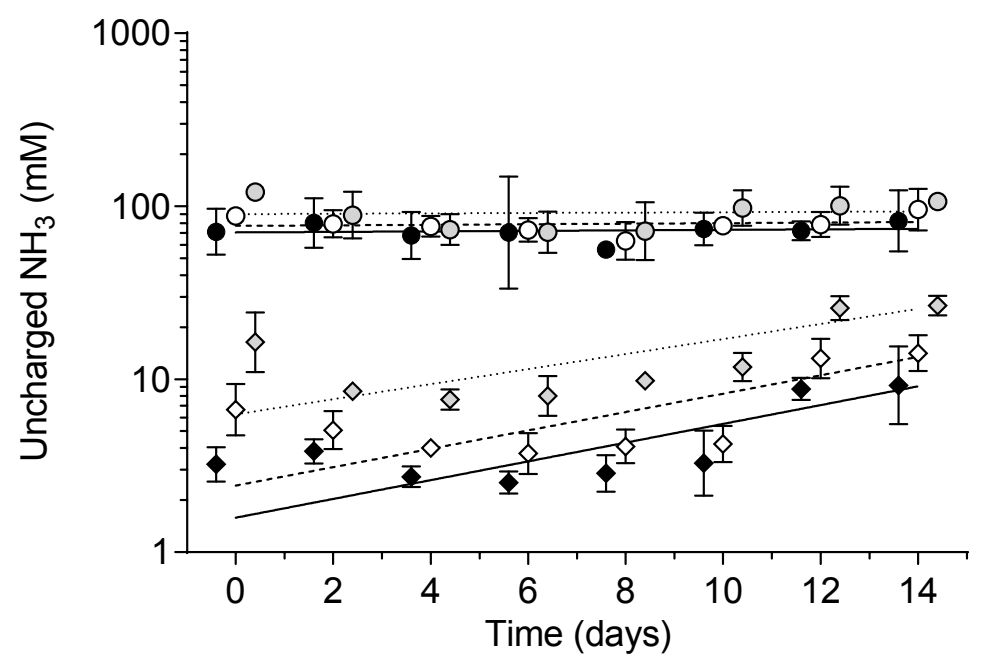

Figure 1. 


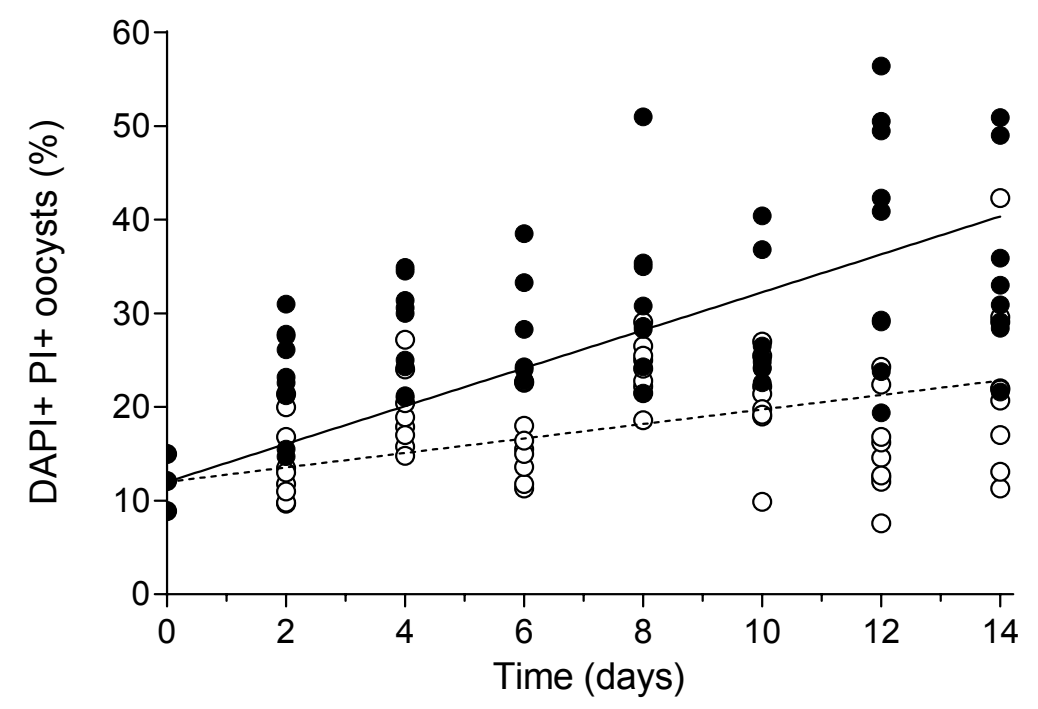

B

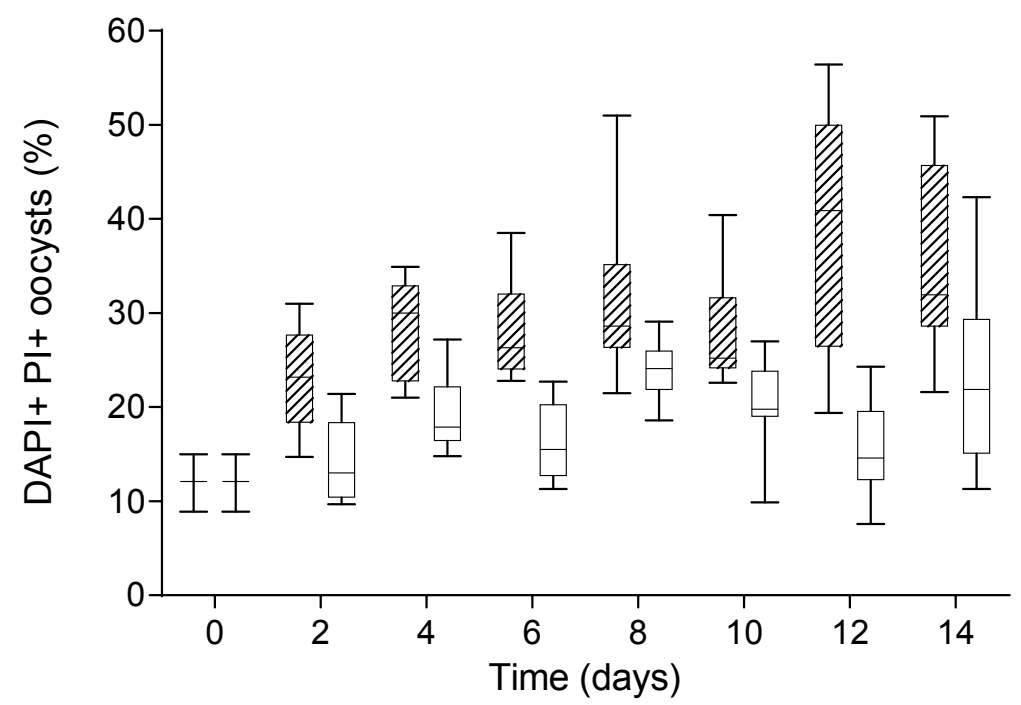

Figure 2. 
A)
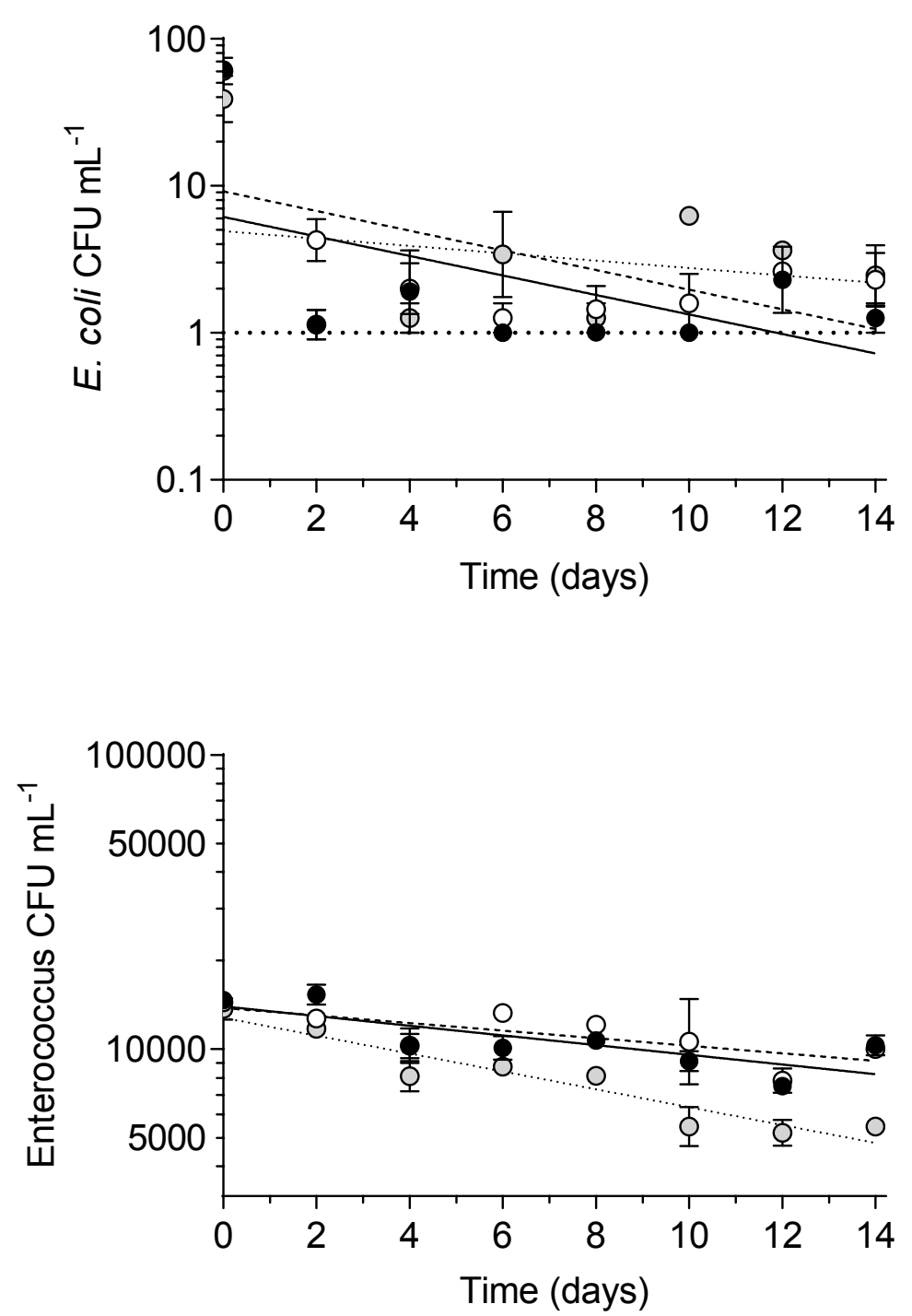

B)
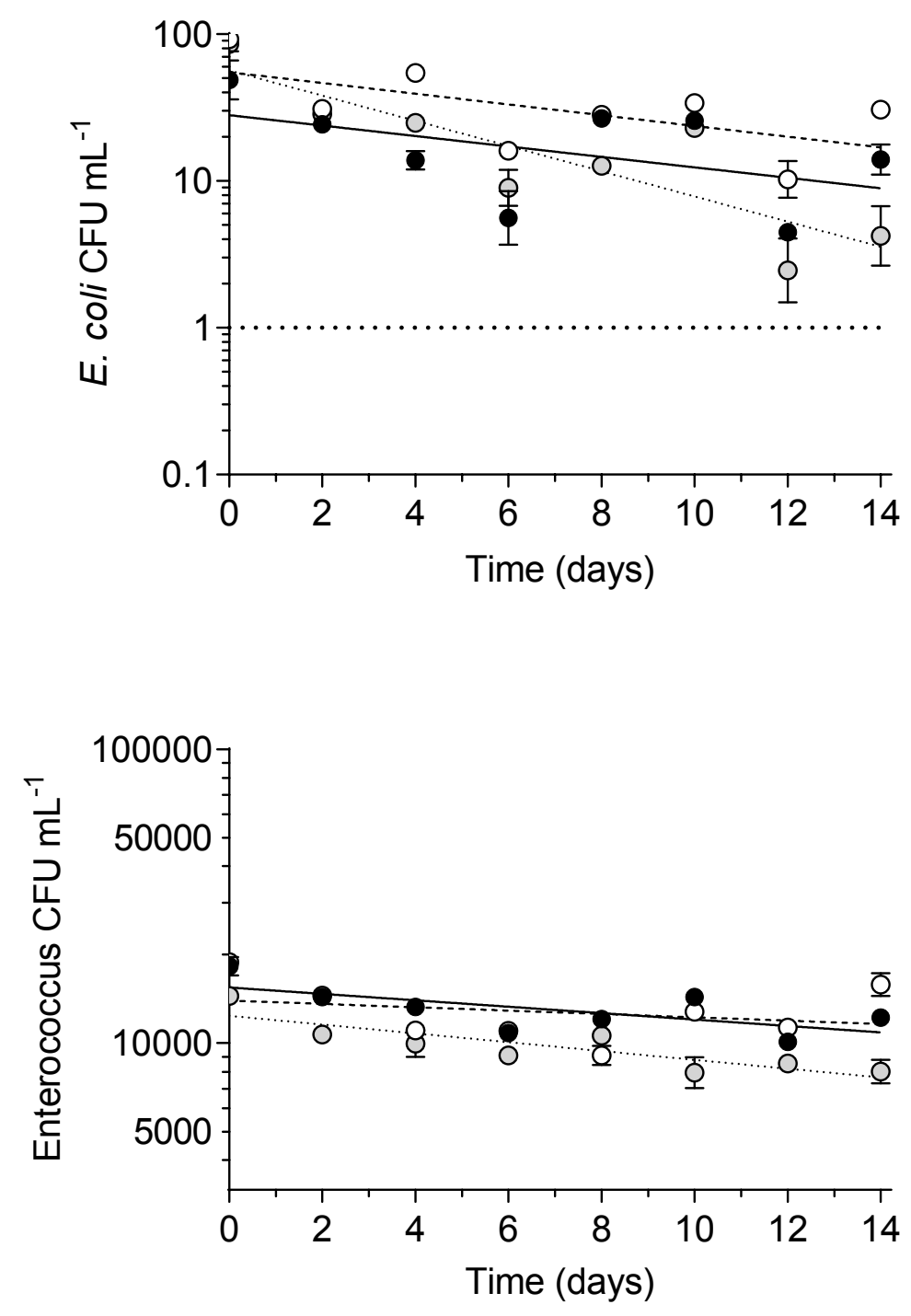

Figure 3

This article is protected by copyright. All rights reserved 
A)

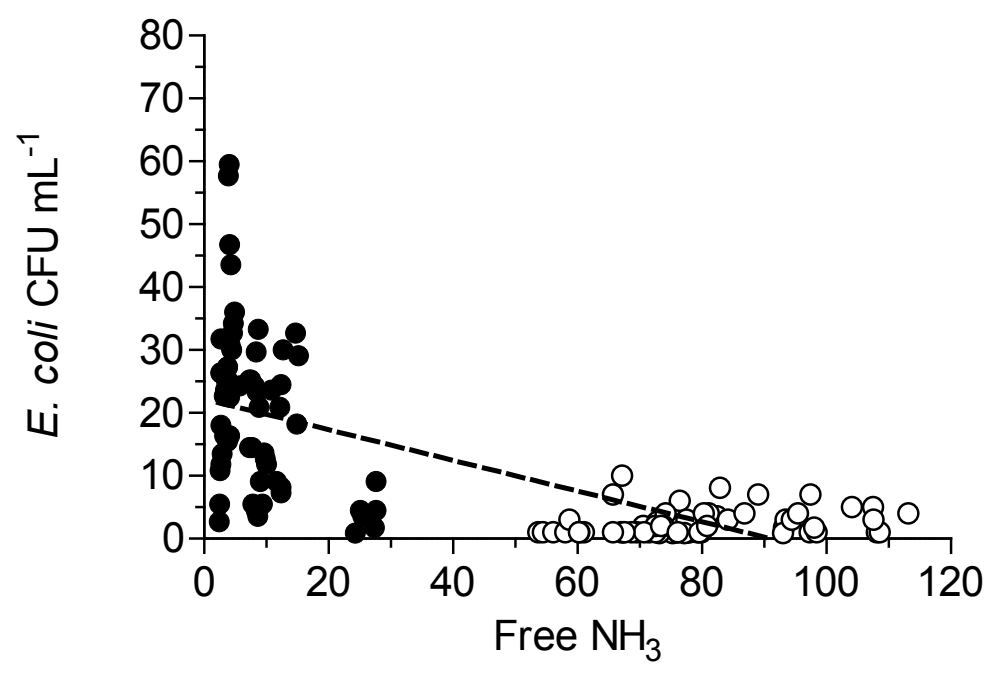

B)

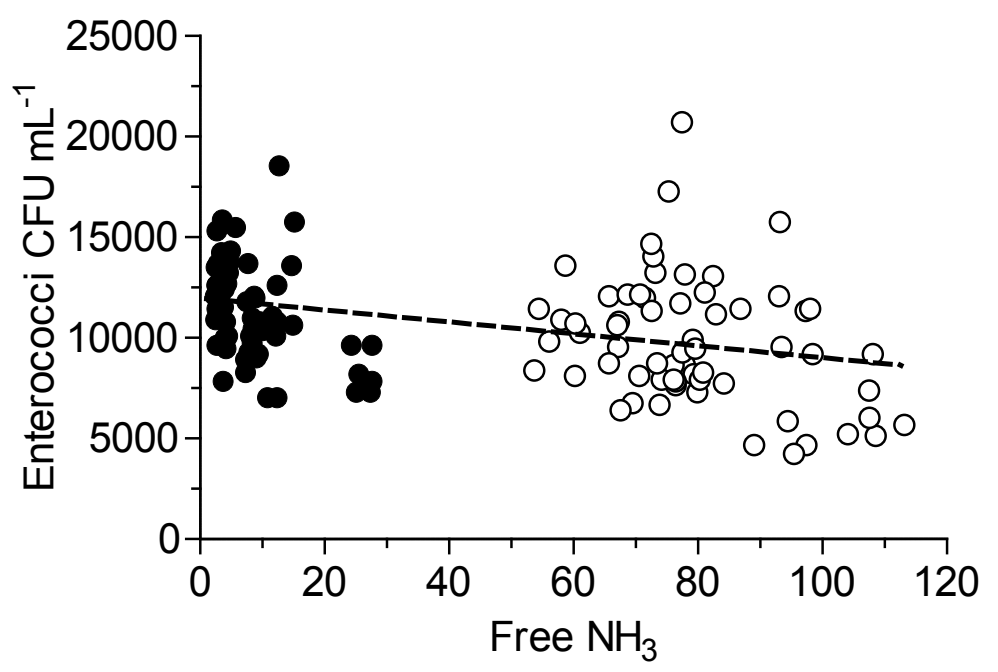

Figure 4 